
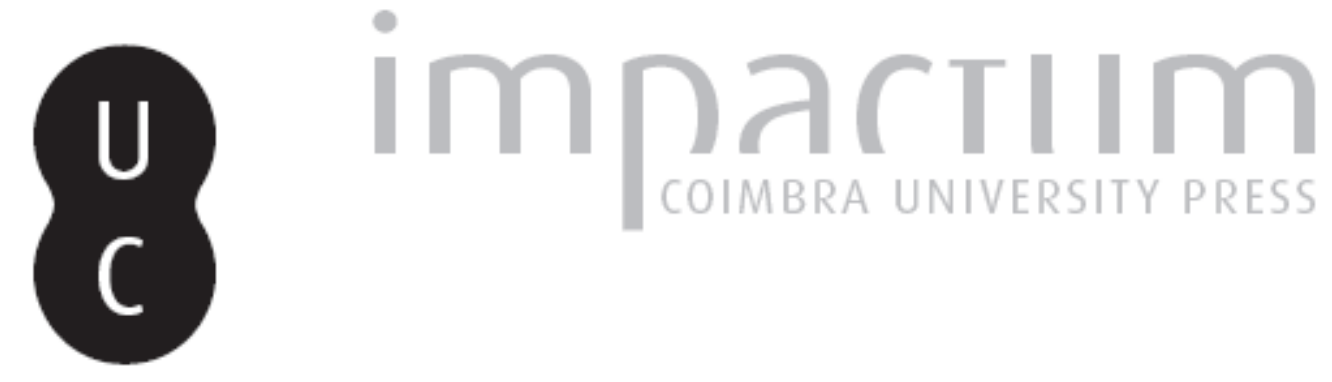

\title{
Ecos do 1ำ centenário da Revolução Francesa na imprensa regional de Coimbra
}

Autor(es): $\quad$ Roque, João Lourenço

Publicado por: Imprensa da Universidade de Coimbra

URL persistente:

URl:http://hdl.handle.net/10316.2/43791

DOI:

DOI:https://doi.org/10.14195/2183-8925_10_32

Accessed : $\quad$ 26-Apr-2023 11:50:02

A navegação consulta e descarregamento dos títulos inseridos nas Bibliotecas Digitais UC Digitalis, UC Pombalina e UC Impactum, pressupõem a aceitação plena e sem reservas dos Termos e Condições de Uso destas Bibliotecas Digitais, disponíveis em https://digitalis.uc.pt/pt-pt/termos.

Conforme exposto nos referidos Termos e Condições de Uso, o descarregamento de títulos de acesso restrito requer uma licença válida de autorização devendo o utilizador aceder ao(s) documento(s) a partir de um endereço de IP da instituição detentora da supramencionada licença.

Ao utilizador é apenas permitido o descarregamento para uso pessoal, pelo que o emprego do(s) título(s) descarregado(s) para outro fim, designadamente comercial, carece de autorização do respetivo autor ou editor da obra.

Na medida em que todas as obras da UC Digitalis se encontram protegidas pelo Código do Direito de Autor e Direitos Conexos e demais legislação aplicável, toda a cópia, parcial ou total, deste documento, nos casos em que é legalmente admitida, deverá conter ou fazer-se acompanhar por este aviso.

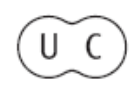


REVISTA DE HISTORIA DAS IDEIAS IO
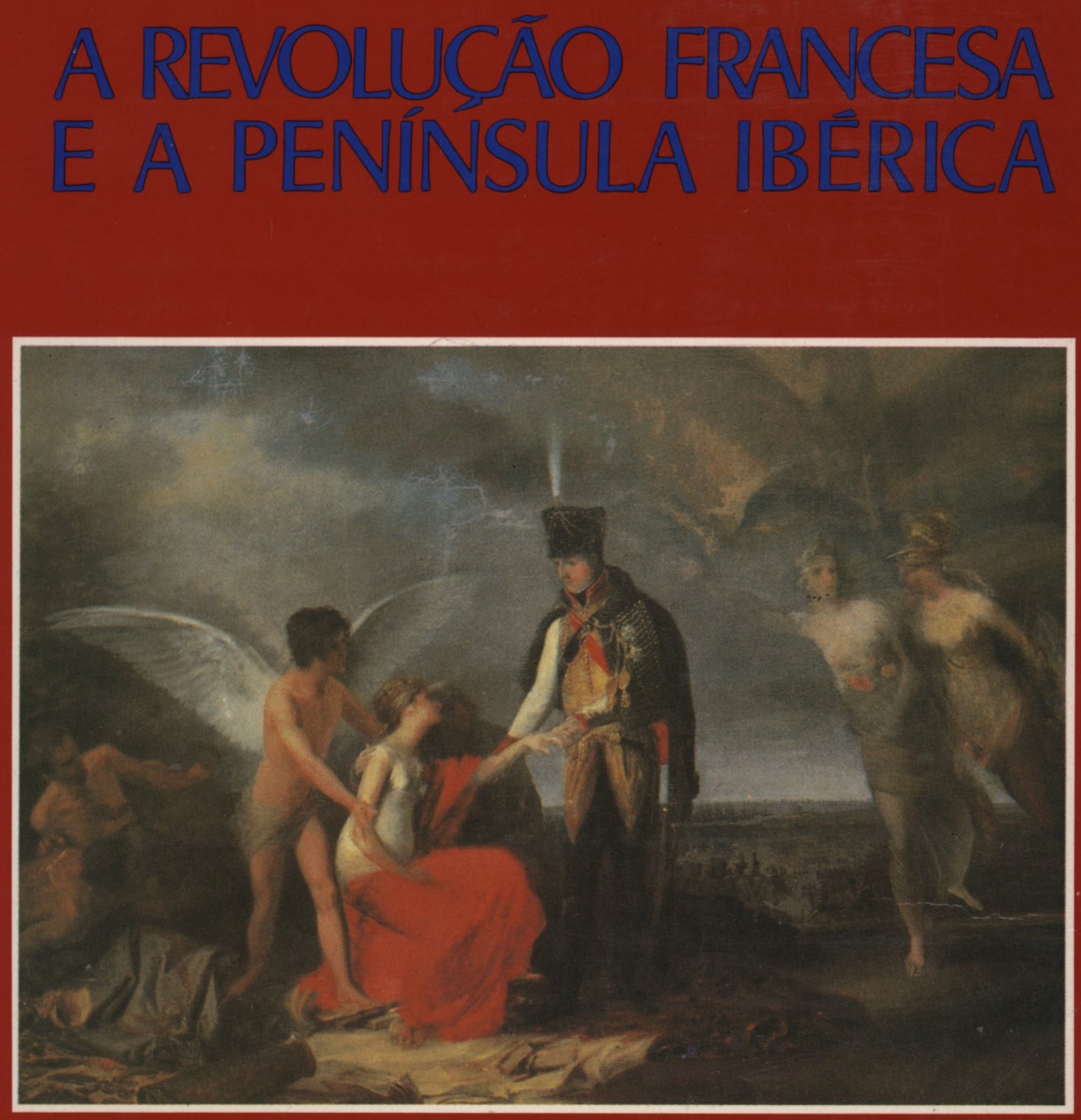

INSTITUTO DE HISTÖRIA E TEORIA DAS IDEIAS FACULDADE DE LETRAS 
JOAO LOURENÇO ROQUE *

\section{ECOS DO $10^{\circ}$ CENTENÁRIO \\ DA REVOLUÇÃO FRANCESA \\ NA IMPRENSA REGIONAL DE COIMBRA}

\section{Introdução}

A história acontece. Difícil se torna apreendê-la, ou interpretá-la. Ainda assim, a permanente veleidade e o estimulante desafio de nos apropriarmos do tempo e do espaço.

Aproxima-se o bicentenário da revolução francesa. Revolução marcante e decisiva na liquidação política, social e institucional do postumamente designado «ancien régime». Acto de nascimento, em muitos pontos, da França moderna (a partir, contudo, das tendências de uma evolução secular) e veículo de reacções e de transformações em diferentes países.

Qualificada, em alguns sectores, como a mais completa e radical das revoluções liberais e burguesas - porque luta política e social em várias frentes, porque revolução de revoluções e também porque movimento nacional e internacional - adquiriu ela uma grande dimensão histórica e ideológica, influenciando decisivamente grande parte da história contemporânea, particularmente do Ocidente europeu.

Pelas suas origens e objectivos; pelos seus percursos e trajectórias; pelos seus princípios ou divisas de sentido universal e pelos seus desvios; pela sua obra duradoura (em consonância com os interesses e as convicções da burguesia) e pelas suas antecipações (caso dos direitos políticos e sociais reconhecidos às massas populares no conturbado período da ditadura jacobina); pelas alterações que (por reacção ou contágio) suscitou ou estimulou a nível externo; pelas divisões, conflitos e dramas que semeou, etc.; a revolução de 1789 tem, desde então, motivado sentimentos contraditórios e alimentado significativas polémicas.

* Faculdade de Letras da Universidade de Coimbra. 
Além disso, sucessivas gerações de historiadores e de outros estudiosos erigiram-na em terreno privilegiado das suas pesquisas e reflexões.

Consequentemente, é bastante rica e multifacetada a historiografia da revolução. Ainda assim, importará desenvolvê-la e diversificá-la. Daí o interesse da presente reunião científica que (na linha de anteriores e posteriores iniciativas) visa aproveitar da melhor maneira a efeméride do bicentenário, ocupando-se de variados temas e questões inseridos no âmbito da revolução no espaço peninsular ibérico. Espaço em que determinadas repercussões daquela (bem como de ulteriores acontecimentos) se registaram de modo relevante e trágico (em alguns aspectos).

\section{Objectivos e fontes}

Tendo em conta a significativa projeç̧ão histórica e ideológica da revolução de 1789 e a importância que, desde o século XIX, se passou a atribuir ao «julgamento» e à «comemoração» dos grandes acontecimentos e episódios na vida dos povos e dos indivíduos, procurou-se averiguar até que ponto (e de que modos e perspectivas) se assinalou na imprensa de Coimbra o 1. centenário da revolução. Ou seja, tentar vislumbrar como, à distância de um século (ou a pretexto da singularidade e relevância evocativa que um século sempre representa na memória das gerações) e no quadro de uma cidade «periférica» e relativamente longínqua do "país revolucionário», o evento e suas repercussões ainda ecoavam ou afloravam.

A pesquisa abrangeu os seguintes jornais ou revistas (em publicação em 1889):

a) Com informação que parcialmente utilizei: $O$ Conimbricense, Correspondencia de Coimbra, O Imparcial de Coimbra, O Tribuna Popular, A Officina, A Voz do Artista, O Sargento, A Ordem, Instituições Christãs, Jornal para todos, Coimbra Medica.

b) Sem elementos respeitantes ao tema: Jornal Militar, Bohemia Nova, Bohemia Velha, A Via Latina, A Sciencia Catholica, O Instituto, Revista de Legislação e Jurisprudencia, Boletim da Sociedade Broteriana.

3. Resumo e interpretação dos elementos coligidos: a revolução em julgamento

3.1. Actos comemorativos locais: o 14 de Julho - alvorada e símbolo da liberdade; a pena de morte em causa.

Apenas o Atheneu Popular (instituto de instrução, agremiação operária) realizou uma sessão solene comemorativa do 14 


\section{Centenário na Imprensa Regional de Coimbra}

de Julho, da qual se ocuparam somente dois jornais: $O$ Conimbricense e $A$ Officina - com mais detalhe o segundo $\left(^{1}\right)$, justificando-se a iniciativa (na expressão do primeiro) «por d'essa data dimanarem todas as reformas liberaes que gosam os paizes cultos». Acto singular, pois, num meio apontado como «perfeitamente conservador».

Teve lugar na própria sala de sessões do Atheneu, no edifício do Carmo, que se encontrava «singelamente adornada de hera. Nas paredes viam-se bandeiras symetricamente dispostas, achando-se nos escudos os nomes dos encyclopedistas francezes...., e o dos agitadores que completaram a obra gigantesca por elles iniciada». Figuravam igualmente alguns homens célebres, do passado e do presente, em diferentes domínios. A música marcou presença: uma orquestra abriu com o hino do Atheneu e tocava nos intervalos.

Em Coimbra, a lembrança da hera - símbolo clássico da vitalidade. Acaso simples, ou anseio e esperança de perenidade na «memória» de «grandes acontecimentos»?

Neste singelo cenário alegórico, o presumível entusiasmo das palavras.

Presidiu à assembleia, por proposta do presidente da direcção do Atheneu (Benjamim Gonçalves), um estudante da Universidade (Lomelino de Freitas), secretariado por dois tipógrafos (Delphim Gomes e Candido Nazareth), sócios da colectividade.

Foram lidas «mensagens de congratulação», «enviadas ao Atheneu, pelos jornalistas dos principaes periodicos republicanos de Lisboa e Porto, escriptores e parlamentares do mesmo partido». Leu-se também a «mensagem» de Alves Miranda, «intelli亏ente operario d'esta cidade, o qual não poude ir pessoalmente ássociar-se a este acto, pelos seus padecimentos physicos».

Discursaram Ramiro Pereira, Ferreira da Silva, Delphim Gomes e Lomelino de Freitas $\left(^{2}\right)$. De entre as ideias avançadas, talvez se possa realçar a «leitura» e a comemoração da revolução como movimento de liberdade dos povos e de progresso.

$\mathrm{Na}$ admiração da obra revolucionária e da França, a «espessa nodoa», contudo, da conservação da guilhotina, na «florescente

(1) Cf. O Conimbricense, n. 4367 , de $9 / 7 / 1889$, p. 3, col. 4 (que insere a notícia "Atheneu Popular», anunciando a realização da referida sessão) e n. ${ }^{\circ} 4369$, de $16 / 7 / 1889$, p. 2 , cols. $2-3$ (em que, sob o título de «14 de Julho», Joaquim Martins de Carvalho resume tal festa) - e A Officina (VII anno), n. ${ }^{\circ} 339$ (de $14 / 7 / 1889$, p. 1, col. 4) e 340 (de 20/7/1889, pp. 1-2), nos quais (sob o título de "Atheneu Popular» e "O Atheneu Popular»), respectivamente, se anuncia e relata aquela sessão.

(2) A Officina (n. 340 , cit.) publicou na íntegra o discurso de Delphim Gomes e resumos dos demais. 


\section{Revista de História das Ideias}

republica». Conforme frisou Delphim Gomes no final do seu discurso e que, nesse sentido, fez uma proposta, muito aplaudida, a qual viria a concretizar-se no seguinte telegrama, dirigido ao embaixador francês em Lisboa: «A assembleia do Atheneu Popular de Coimbra, em commemoração solemne do centenario da tomada da Bastilha, saúda a grande nação franceza, e pede para que participeis ao vosso chefe d'estado os seus votos para serem junctos aos de todos aquelles que neste momento de confraternisação lhes imploram a abolição da pena de morte».

Do relato desta «festa», numa noite de Coimbra, a propósito da "gloriosa data» amanhecida revolução na história de um século, haverá que sublinhar a convergência de uma parte do meio intelectual e operário (de convicções republicanas e aspirações de "classe») na exaltação de um dos principais símbolos da revolução francesa (bem como do seu significado e influências) e, em consonância com uma linha humanitária progressista, a condenação da pena de morte (de há muito abolida em Portugal). Atitude que já antes havia sido assumida claramente num dos jornais aqui utilizados. Acrescente-se que na formulação de tais votos interviria também, provavelmente, a consciência ou o sentimento de que a manutenção daquela pena (no próprio país arvorado em fonte ou modelo de civilização e de progresso) deslustrava os princípios de 89 e a «imagem» da república (entre outras instituições).

3.2. $A$ posição de alguns periódicos e revistas, relativamente ao movimento revolucionário.

3.2.1. Orgãos representativos de correntes ou partidos do quadro liberal $e$ constitucional: genericamente a defesa do legado politico da revolução a par de algumas censuras ou divergências sectoriais.

3.2.1.1. O Conimbricense: no elogio da França como fonte e exemplo de liberdade e de civilização - algumas reservas ou críticas (sobretudo, a barbárie da pena de morte).

Da autoria do seu director, Joaquim Martins de Carvalho, publicou este importante jornal alguns artigos em que, de modo indirecto, se aprecia a revolução.

No primeiro deles - intitulado «A pena de morte em França» $\left(^{3}\right)$ - reconhece-se o contributo civilizador daquele país, em diversas áreas, e a gratidão que lhe é devida pelos "paizes que antes de 1789 viviam sob o jugo do absolutismo e dos mais

(3) O Conimbricense, n. 4315 , de 5/1/1889, p. 1. 


\section{Centenário na Imprensa Regional de Coimbra}

oppressivos privilegios», e reprova-se expressivamente a manutenção da pena capital como «pratica barbara e odiosissíma» e «affronta da philosophia e da civilisação!».

O articulista condena mais ainda a «satisfação» e a «avidez» com que o povo francês procurava ainda então (conforme um exemplo recente que narra) tal «espectaculo». À semelhança ào que acontecia em Portugal nos tempos da Inquisição e do que se verificava em Paris no período de 1792 a 1795 na praça da Revolução, onde «as furias da guilhotina iam da maneira mais Ignobil insultar os condemnados».

Em suma, alude-se indirectamente à importância histórica da revolução (no domínio da liberdade política) e aos reprováveis excessos da fase do terror. Recorde-se, aliás, que a «mcrte espectáculo» era instituição e imagem do antigo regime.

Num artigo sobre "A situação política em França» $\left(^{4}\right)$, em torno dos presumíveis intentos e aspirações ditatoriais do general Boulanger (à semelhança do que aconteceu com Napoleão e seu sobrinho Luís Napoleão), refere-se de novo, nas passagens finais, o alcance da revolução - à qual «se deve a transformação política e até certo ponto social da França e outros muitos paizes da Europa» - verberando-se que (com o auxílio da cisão dos republicanos) se pretenda, justamente em 1889, «no centenario da grande revolução», em vias de brilhante comemoração, «exautorar a França, elegendo um espadão para deputado, como preparativo para uma dictadura militar!» ( $\left.{ }^{5}\right)$.

$\mathrm{Na}$ pequenez do espaço dedicado ao assunto $\left({ }^{6}\right)$, ainda assim á força das ideias liberais e da nação francesa.

3.2.1.2. Correspondencia de Coimbra: no silêncio de outras apreciações, o terror em causa.

Neste periódico só acidentalmente, e a propósito de um assunto distinto, se comentou uma determinada fase da revolu-

(4) Ibidem, n. 4318, de 15/1/1839. p. 2.

(5) Joaquim Martins de Carvalho publicou também outro artigo sobre «Bovlanger e Luiz Bonaparte» (ibidem, n.o 4319, de 19/1/1889, pp. 1-2). Encontram-se também no jornal várias notícias sobre Boulanger.

$\left.{ }^{(}\right)$A título de curiosidade, refira-se que Joaquim Martins de Carvalho (sob o título de «100 Annos») saúda o centésimo aniversário de D. Theresa Amalia Eusebia Falcão, natural e residente em Pousafoles (concelho de Miranda do Corvo), viúva de Eusébio Francisco Fernandes Falcão («sendo ambos e toda a família presos durante o intolerante governo de D. Miguel, de 1828 a 1834»). a qual nasceu "um dia antes da abertura dos estados geraes em França. succedida em 5 de Maio de 1789" (O Conimbricense, n. 4349 , de 4/5/1889, p. 2, col. 1).

De entre algumas publicações noticiadas neste jornal, refira-se a Historia da revolução franceza de Luiz Blanc. 


\section{Revista de História das Ideias}

ção. Num artigo, intitulado "O marquez de Thomar» ( $\left.{ }^{7}\right)$, a quem (por ocasião do seu falecimento, em S. João da Foz do Douro, em 1 de Setembro de 1889) se presta homenagem $\left({ }^{8}\right)$, ao referenciar-se a sua emergência na cena política e ideológica, a partir da revolução de Setembro de 1836, considera-se que António Bernardo da Costa Cabral, filiado no «club dos Camillos em Lisboa», se tornou aí "um dos mais energicos e eloquentes oradores, o mais exaltado certamente de todos os adeptos d'aquella temivel associação, que timbrava em seguir os principios da revolução franceza de 1789 , e à qual não fariam estremecer nem os horrores da nefasta época de 1793».

Marginalmente, portanto, sugestiva (e frequente, em quadrantes diversos) reprovação do «terror de 1793» (expressão utilizada, mais adiante).

\subsubsection{O Imparcial de Coimbra: as lições da França e uma revolução com saldo favorável.}

O tema é contemplado num artigo intitulado «Considerações: $\left(^{9}\right)$, em que, criticamente, se confrontam o comportamento em grande medida exemplar da França (devotada à maravilhosa «commemoração do acontecimento mais estrondoso do seculo passado») com a mesquinhez da vida política nacional.

Reconhece-se que a revolução não constituiu «um dia sem sombras, uma primavera sem manchas». Mas, segundo se adianta, dessa agitada e contraditória época, de significativas vicissitudes, reteve a França «o melhor ouro da campanha, o mais precioso espolio da batalha, - que eram as regalias publicas, as liberdades políticas da numerosa classe popular deduzidas por legítimo direito às classes privilegiadas e desde tão longa data unicos preponderantes».

Motivos de admiração pelo povo francês fornecia-os igualmente o presente, considerando-se que «emquanto o boulangismo agitava as azas ensaiando-se para vôos audazes, uma alta inteligencia presidia aos trabalhos do centenário, a torre Eiffel subia gradualmente acima dos pyramides do Egypto, e este pensa-

(7) Correspondencia de Coimbra (anno XVIII, n..$^{\circ} 71$, de 10/9/1889, pp. 1-2), da autoria de um «talento previlegiado e escriptor primoroso" (ibidem. p 2 col. 3).

( ${ }^{6}$ Qualificando-o, apesar da oposição política (confessando o autor do artigo que nunca militou no seu partido plítico e que sempre o guerreou na medida das suas forças), de "gigante», "grande estadista» e o "mais energico vulto do reinado de D. Maria II».

(9) O Imparcial de Coimbra (anno VII), n..$^{\circ} 828$, de 18/6/1889, p. 1, cols. 1-2. 


\section{Centenário na Imprensa Regional de Coimbra}

mento patriotico, grave, profundo, intenso não tinha força que o desviasse um apice do seu aprumo vigoroso e varonil».

Em suma, o ontem e o hoje associados em lição e em reflexão crítica.

E com a torre Eiffel acima das pirâmides, quiçá o sentimento de um voo ascendente da história, na pátria da revolução e à medida da sua grandeza...

3.2.2. Imprensa militar: O Sargento (órgão dos officiaes inferiores do exercito portuguez): o 14 de Julho, exemplo libertador

O único juízo formulado neste semanário relativamente a 1789, insere-se numa mensagem - com o título de «Camaradas» $\left({ }^{10}\right)$ - a propósito do primeiro aniversário do jornal (a 29 de Julho), acontecimento que para eles «devia ser tão festejado, mutatis mutandis, como.... o 14 de julho em França».

Considera-se, textualmente, que ele «anniquilou os despotas e devassos que opprimiam e depauperavam o povo, fazendo-lhes ver quanto os pequenos podem, sempre que se unam». E que «abriu de par em par as portas da civilisação, e fez ver ao mundo inteiro qual o caminho que todos os povos têm a seguir para a sua completa emancipação».

Uma data enaltecida, pois, enquanto simbologia e matriz de experiência.

3.2.3. Imprensa operária: exaltação da França e apologia da revolução ascendente (ponto de partida e ruptura); a revolução como um bem.

3.2.3.1. A Officina (semanário da classe operária): na evocação de algumas datas, a glorificação de um povo - arquitecto da liberdade $e$ arauto do futuro.

Assinalou este jornal algumas datas principais, enquanto marcos e jornadas num movimento de libertação universal.

Num artigo intitulado «Jubileu da Democracia», da autoria de Delphim Gomes ( $\left.{ }^{11}\right)$, recorda-se em 5 de Maio a «alvorada da revolução franceza», com a reunião dos Estados Gerais que, contrariamente aos intentos de Luís XVI que almejaria amparo «na sua ruina», redundaram na sua condenação.

A assembleia veio a assumir «um caracter desassombrado e iniciou uma nova era na historia: proclamou a egualdade politica e civil, supprimiu as classes e os privilegios senhoris,

(10) Da autoria de Marcellino de Campos, in $O$ Sargento (anno II , n..$^{\circ} 53$, de $12 / 8 / 1889$, p. 1 , cols. $3-4$.

(11) A Officina, n. 330 , de $10 / 5 / 1889$, p. 1, cols. $1-2$. 
iançou na escola as raizes da educação civica e nos espiritos o germen da reorganização intellectual».

Consequentemente, "essa lucta desenfreada e terrorista, reparadora dos delictos e erros do passado, que ensanguentou um povo mas que preparou a emancipação da humanidade inteira».

Daí que a França seja «abominada pelos escravos voluntarios das instituições caducas». Mas ela permanecerá como «a grande metropole do pensamento e a collossal patria do progresso!».

À qual se atribui nova missão. Pois que, havendo ela, um século atrás, libertado «da sujeição feudal e canonica o terceiro estado - a burguesia», lhe incumbe no presente "alforriar do predominio capitalista o quarto estado - o proletariado». A «cúpula» que deve construir para o "edifício» que ergueu. Sublinhe-se, de permeio, a associação ou equivalência de diferente vocabulário social.

Num artigo relativo a «14 de julho de 1789 » ${ }^{12}$ ), considera-se «esta a mais gloriosa data que brilha nos fastos da emancipação do espirito humano», apontando-se a «tomada da Bastilha» como «o facto mais significativo, mais heroico e mais sympathico de toda essa grandiosa e sanguinolenta epopêa que se chama a Revolução Franceza».

Constituiu aquela um sinal e uma ameaça de destruição da «tyrannia do direito divino». Mas, ante o comportamento do rei e da corte, Luís XVI viria a expiar «no cadafalso os crimes da sua raça», vitimado pelos "proprios erros de conspirador nefasto e de traidor odioso».

Em fundamento de um tal juízo invocam-se factos, sentenciando-se assim:

«A justiça popular feriu recta e implacável!

Nem só o sangue da plebe, d'esses anonymos obscuros e esfaimados, devia servir para cimentar os alicerces do edificio da moderna democracia!»

E. consequentemente, adianta-se o seguinte:

«Honremos a memoria sagrada de todos esses revolucionarios, benemeritos da civilisação, victimas heroicas, devotadas ao grande sacrificio, que operou a mais completa transformação na vida das nacões, pela conquista de novos direitos e de novas garantias de liberdade, - pelo reconhecimento da soberania do povo!»

Em síntese, a propósito da evocação do 14 de Julho, a natural condenação do trono (e de seus aliados). Na decrepitude e nas culpas da monarquia, o advento da democracia e da república...

(12) A Officina, n. 339 , de $14 / 7 / 1889$, p. 1, cols. 1-3. 


\section{Centenário na Imprensa Regional de Coimbra}

Outra data registada foi a de $\ll 26$ de Agosto» $\left({ }^{13}\right)$, representando «nas ephemerides da democracia universal, no anno presente, o centenario da declaração dos Direitos do Homem».

Reproduz-se ali «esse famoso documento, que, embora seja falseado pelas instituições monarchicas, é a fonte commum onde todos os espiritos livres vão haurir a garantia das suas regalias».

A par de nova crítica à monarquia, a insistência no carácter inspirador do legado de 89.

3.2.3.2. A Voz do Artista (semanal, dedicada d classe operária): a revolução incompleta (e em projecção)

Numa das suas secções (Pelas Folhas), e sob o título de "A revolução de 89 e a revolução social» $\left({ }^{14}\right)$, transcreve parcialmente (e comenta) do Alemquerense (referido como totalmente insuspeito de «socialista»), um artigo de Horacio Ferrari, em que se confrontam a revolução de 1789 (qualificada como tendo sido «em parte, a revolução politica») e a que se prepara para o século XX («crise tremenda», anunciada como «a revolução social»):

A primeira «proclamou os principios do progresso humano»; a segunda «ha de effectuar a sua realisação. Aquella foi a revolução dos burguezes, ricos, instruidos, trabalhadores e ambiciosos; esta será a dos pobres, a dos maltrapilhos, a dos miseraveis, a dos que, por mais que trabalhem, não levantam cabeça, e vêem morrer-lhes de fome e doenças da mizeria os filhos e as mulheres».

Numa outra passagem transcrita, felicita-se a França pela «celebração do centenario glorioso da sua Revolução» e adverte-se sobre a caminhada que falta para alcançar «a realisação dos principios humanitarios proclamados por alguns dos promotores d'essa grande luta».

Em comentário final, ao que transcreveu da referida folha, A Voz do Artista alinha pela ideia de que - «nada está realisado; tudo se acha apenas proclamado» - , pelo que «a obra da proxima revolução» não poderá cingir-se simplesmente a uma alteração do regime (governos republicanos em vez de governos monárquicos) e à «luta economica». Fórmula de advogar revolução em pensamento socialista?

(13) Ibidem, n. 345. de 24/8/1889. pp. 1-2.

(14) A Voz do Artista (5. anno), n. 169 , de 15/5/1889, p. 2, col. 3. Fublicou também um apontamento (ou relato) sobre - "A Tomada da Bastilha" - , de Henri Martin (quiçá extraído da obra Histoire de la révolution française de 1789 à 1799, Paris, 1882), n. 176. de 19/7/1889, p. 1, cols. 1-2. 
Nesta breve recordação de 1789 , a ideia de que os seus princípios deverão consumar-se numa outra revolução (a das massas populares, em contraste com a da burguesia). Ou seja, a lembrança de 89 como ponto de partida (ou etapa) de maiores transformações - o que sugere alguma convergência com 0 jornal anterior.

3.2.4. Imprensa da área tradicionalista e da esfera católica: a condenação da revolução; a apologia da tradição e da ordem social religiosa (ou seja, uma posição extrema comparativamente à da imprensa operária; mas ambas de sentido maniqueísta»).

3.2.4.1. A Ordem: a revolução como um mal (a nível religioso, político e social) e um fracasso.

Dos jornais consultados foi este o que mais espaço dedicou ao tema, contemplando-o em várias secções e sempre numa perspectiva igualmente apaixonada, negativa e anti-revolucionária.

Assim, na «Intenção geral do mez de janeiro de 1889» sobre «A restauração dos direitos de Deus» $\left({ }^{15}\right)$, anuncia-se que «A maçonaria franceza vae celebrar com esplendor nunca visto e enthusiasmo encommendado o centenario da Revolução de 1789. Só o annuncio d'estes projectos de festas tem abalado, até nos paizes mais remotos, todos os Catholicos verdadeiramente dignos d'este nome, os quaes consideram, com razão, esta celebração solemne como um desafio publico e execravel attentado contra Deus, capaz de attrahir sobre as nações castigos bem merecidos».

Comentam-se os «falsos dogmas, ou a Declaração dos Direitos do homem», qualificada como «uma impudente e inepta declaração de guerra a Deus e a Jesus Christo», contrapondo ao seu enunciado os direitos divinos.

Por exemplo, contra o princípio de que «toda a soberania reside essencialmente na nação», arvora-se a origem divina da autoridade e do poder.

$\mathrm{E}$ em lugar da proclamada e prometida felicidade (essa «ideia nova» na Europa do século XVIII, recorde-se), as populações antigamente «felizes e pacificas» - ora «desgraçadas, descontentes da sua sorte, e turbulentas».

Adiante-se que, num artigo intitulado «O Pauperismo» $\left({ }^{16}\right)$, se responsabiliza concretamente a revolução (e antes dela o protestantismo, em alguns países) pelo aparecimento generalizado daquele flagelo, ao extinguir os bens eclesiásticos e as ordens religiosas, tolhendo assim a influência da Igreja Católica que, por

(15) A Ordem (XI anno, 1889), n. 1082 , de 2/1/1889, pp. 2-3.

(16) Ibidem, n. ${ }^{\circ} 1171$, de 20/11/1889, p. 1, cols. 1-2. 
meio de uma "caridade sem limites», sempre remediara «tão grande mal».

$\mathrm{Na}$ «Intenção geral do mez de Fevereiro» sobre «As victimas do orgulho» $\left({ }^{17}\right)$, a Declaração volta a estar, em parte, em causa, enquanto «voz de rebellião contra Deus - o non serviam do mundo moderno, o grito do orgulho humano, cumplice do infernal dragão, que de novo veio tentar os filhos de Eva com promessas fementidas». $\mathbf{E}$ isso essencialmente pelas suas posições quanto à origem da soberania e da autoridade.

Considera-se a «Revolução» como «uma doutrina e doutrina do orgulho», cujos triunfos não surpreenderiam atendendo a que, entre outras condições, «a maçonaria, com sua preponderancia nos Estados modernos e com o seu ouro judaico, com a sua imprensa desbragada e com o ensino da juventude, entregue quasi inteiramente em suas mãos, é quem a protege e lhe inspira o veneno do orgulho, de que ella propria está saturada».

Sublinhe-se a insistência na associação entre o quadro revolucionário e a maçonaria (força bastante actuante no século XIX), sustentada pela riqueza judaica. Numa linha, quanto a estes, de preconceitos simplesmente religiosos ou também raciais e anti-capitalistas?

$\mathrm{Na}$ «Intenção geral do mez de Maio» sobre «A conversão dos judeus» $\left({ }^{18}\right)$, refere-se o notório aproveitamento da revolução pelos judeus e cita-se a afirmação de um deles (Cahen nos Archivos Israelitas), em 1847, de que «O Messias veio para nós com a Declaração dos direitos do homem».

$\mathrm{Na}$ «Intenção geral do mez de Agosto» sobre «A abolição da escravatura» $\left({ }^{19}\right)$, contesta-se o «dogma» de que pela primeira vez se concedeu ao mundo «a carta d'alforria quando os revolucionarios francezes decretaram, em palavras, a libertação do genero humano», tornando-se claro "que sem a acção libertadora do Christianismo, por elles repudiado, jámais a humanidade, àegradada pelo peccado original, se libertaria do juro da escravidão».

Num artigo sob o título de «O Centenario de 1789» - reproauzido da Correspondencia de Roma, de 11 de Maio de $1889\left({ }^{(20}\right)$, - apontam-se «O odio e a destruição da ordem religiosa e social» como «a essencia e a historia d'aquella epocha infernal». Evoca-se, assim, com detalhe a obra destruidora da revolução a nível material (com a «guerra às cousas»), a nível humano («pela

(17) Ibidem, n. ${ }^{\circ} 1090$, de $30 / 1 / 1889$, p. 2, cols. 14 .

(18) A Ordem, n. $4 / 5 / 1889$, pp. 2-3.

(19) Ibidem, n..$^{1138}$, de $27 / 7 / 1889$, p. 2 , cols. $4-5$.

(20) Ibidem, n. ${ }^{\circ} 1120$, de $18 / 5 / 1889$, p. 2, cols. 3-5. 
guerra implacavel e feroz às pessoas») e religioso. Alude-se à guerra que semeou na Europa e às convulsões originadas pelos seus «princípios».

Numa notícia denominada - «Viva a liberdade!...»-( $\left.{ }^{21}\right)$, opresenta-se um quadro estatístico das vítimas da revolução.

Sob o título de «Em Lourdes» $\left({ }^{22}\right)$, regista-se que enquanto «o satanismo revolucionario commemorava em Paris os dias tristissimos da Revolução, em Lourdes foram preparadas solemnissimas festas religiosas para a inauguração da egreja do Rozario». Às quais concorreram "muitos milhares de peregrinos» $€ 16$ «arcebispos e bispos». E acrescenta-se:

«E assim que o espirito christão se oppõe ao desenfreamento revolucionario. Às festas da impiedade oppõem-se as festas de Jesus e da Santissima Virgem».

Em resumo, neste jornal de pendor tradicionalista e legitimista, mais que denegrida, a revolução surge-nos totalmente contestada e condenada. Nos seus valores e «dogmas»; na sua cbra. $\mathrm{Na}$ sua história e no seu futuro. $\mathrm{E}$ assim, provavelmente, a condenação também do «mundo moderno», ali delineado na subversão e na desordem social e religiosa.

3.2.4.2. Instituições Christãs (23): os horrores da Grande Revolução um espectáculo de sangue e de crimes (exaltação do clero)

Publicou esta revista um longo artigo, repartido por vários números, denominado «O Centenario da Grande Revolução Franceza», da autoria de Egydio Azevedo (24).

(21) Ibidem, n. 1146 . de $24 / 8 / 1889$, p. 3, col. 4 .

(22) Ibidem. n.o 1145 . de $21 / 8 / 1889$, p. 2, col. 3. No mesmo jornal podem ver-se outras referências à revolução nos artigos seguintes: "O Avô Carnot" (n. 1139 , de 31/7/1889, p. 2, cols. 3-4); "Os catholicos e a politica» (n. 1164 , de $26 / 10 / 1889$, p. 1, cols. 1-2); "Notas d'um observador» (Michel des Ormes), "Contemplando o Pantheon", trad. (n. 1174, de $30^{\prime} 11 / 1889$, p. 1 , cols. $1-3$, e n. 1176 , de $7 / 12 / 1889$, p. 1 , cols. 1-3) e numa notícia sobre as "Evoluções políticas em França» (n. 1158 , de 5/10/1899, p. 3, col. 1).

${ }^{(23)}$ Revista quinzenal, religiosa, scientifica e litteraria, orgão da Academia de Santo Thomaz d'Aquino no Seminario Episcopal de Coimbra, publicada com approvação do Ex.mo e. Rev.mo Sr. Bispo Conde D. Manuel Corrêa de Bastos Pina, sob a direç̧ão do Arcediago António José da Silva.

(24) Instituições Christãs (VII anno, 1." série. n.o 10, de 20/5/1889, pp. 299-303, n. 11 , de $5 / 6 / 1889$, pp. 327-330, n. 12 , de $20 / 6 / 1889$, pp. 366-369; $2^{2}$ série, n. $^{\circ} 1$, de $5 / 7 / 1889$, pp. $27-30$ n. 2 , de $20 / 7 / 1889$, pp. 41-46, n. 3 , de $5 / 8 / 1889$, pp. $68-71$, n. 4 , de $20 / 8 / 1889$, pp. 97-101, n. 5 , de $5 / 9 / 1889$, pp 134-138, n. 6 , de 20/9/1889, pp. $161-167$, e n. ${ }^{\circ} 7$, de $5 / 10 / 1889$, pp. 201-207), Seminário de Coimbra, Typographia das Instituições Christãs, 1889.

Esta revista publicou também uma notícia sobre «O bispo de Versailles e o centenário" (1. série, n..$^{\circ}$, de $20 / 5 / 1889$, p. 318), que, em 


\section{Centenário na Imprensa Regional de Coimbra}

Constitui este extenso trabalho, uma espécie de resumo (citando vária bibliografia) de diferentes tópicos, no qual, apesar do título (aliás vulgar) se rememora o acontecimento numa sequência de crimes e horrores, apontados em sucessivos capítrilos.

Alvo de celebrações festivas, a França (que o autor confessa admirar e venerar), em cuja história não faltam "glorias» e "prodigiosas virtudes», foi, então, cenário das «scenas mais horrorosas, que jámais foram praticadas em outro povo civilisado».

No capítulo I do seu estudo, o autor trata da - «Tomada da Bastilha» - que, pelas circunstâncias em que ocorreu e pela condição e comportamento dos vencedores, constituiu um feito sem honra e sem glória.

No capítulo II (sobre - «Os revolucionarios, os seus espectaculos recreativos e a sua ferocidade nos supplicios»), aborda os seguintes aspectos:

- o saque dos templos, a confiscação dos bens do clero e a dissolução das ordens religiosas; a constituição civil do clero; o culto da razão (num quadro de «erros e paixões», de "vícios abomináveis», de sacrilégios, etc.); alguns exemplos de «monstruosos crimes» e "o prazer dos ferocissimos tigres da revoluşão, ao saborearem os tormentos e a morte das suas victimas».

No capítulo III, sobre - «Violentos expedientes do governo revolucionario», focam-se:

- (quanto aos «presumidos adversarios») a emigração forçada, a prisão dos suspeitos (em trágicas condições) e a condenação à morte ( (hhorroroso capitulo de miserias e de crimes», por parte de "seres que, tendo a fórma e a figura de homens, se apresentavam mais sedentos de sangue, do que a hyena ou o (hacal»); «a espoliação completa dos cidadãos» (a nível colectivo e individual); "a promulgação de decretos contra muitas instituições excellentes, ...., e especialmente contra a religião catholica e os seus ministros».

No capítulo IV, fala do - «Caracter nobre e virtuoso do clero francez do seculo passado».

No capítulo V, trata da - «Horrivel mortandade do clero francez no seculo XVIII», exemplificando, sobretudo, com o sucedido no início de Setembro de 1792, no convento do Carmo, em Paris. transformado no mês anterior em prisão.

No capítulo VI, sobre - «Mais victimas innocentes da revolução», narra o suplício de religiosas (em 1794).

5 de Maio, participou na recepção ao Presidente da República para que fora convidado, tendo-lhe inclusive dirigido algumas sugestivas palavras (que se reproduzem), mas sem assistir a nenhuma cerimónia civil. 
Por fim, no capítulo VII, uma extensa «Conclusão». Em que se reforça o desolador negativismo da revolução. A esta nem sequer se devem, sendo-lhe falsamente atribuídas, "algumas doutrinas e principios excellentes, como a liberdade, a fraternidade e a egualdade», as quais, além de muito antecedentes, «até foram prégadas pelo christianismo desde os primeiros seculos».

$\mathrm{O}$ autor apresenta-nos, pois, embora sob a invocação da história, um panorama parcial e particularmente sombrio da revolução, rememorada quase exclusivamente em torno do terror, da anarquia e da irreligião.

Atitude certamente em harmonia com os valores humanitários e cristãos e apologética do clero (contudo, parte dele, também comprometido, como se sabe) e da influência institucional є. social da Igreja católica.

$\mathrm{Na}$ condenação da "grande revolução», indigna de quaisquer comemorações festivas, quiçá a defesa de uma civilização.

$\mathrm{E}$ também uma «leitura» da história simplesmente linear c personalista - ainda indiferente à «pressão» das circunstâncias, às motivações e enfrentamentos de grupos e à psicologia das multidões.

\subsection{Informações sobre 1889}

Além das ideias manifestadas relativamente à revolução e ao centenário, quase toda a imprensa assinalou, com maior cu menor atenção, os actos comemorativos em França, mediante pequenas e variadas notícias, alguns artigos ou crónicas, gravuras $\left({ }^{25}\right)$, etc.

(25) Jornal para todos («revista semanal, ilustrada, popular, de sciência, literatura, artes e industria») publicou um artigo de Joaquim Martins Teixeira de Carvalho sobre "O Campo de Marte» (n. 2 , de 13/7/1889, pp. 14-15) e as seguintes cartas de Paris (sobre A Exposição), da autoria do escritor Xavier de Carvalho: I - "Vista geral do Campo de Marte» (n..$^{\circ}$, de 20/7/1889, pp. 21-23); II - "A Torre Eiffel" (n. 4 , de 27/7/1889, pp. 28-30); III - "Ainda a Torre Eiffel» (n..$^{\circ} 7$, de 17/8/1889, pp. 53-54); IV - "O Grande Palacio das Machinas» (n. 8, de 24/8/1889, pp. 58-59).

Simultaneamente, publicou algumas gravuras: uma sobre «A Exposição Universal de Paris - O Campo de Marte» (n. 2 , p. 13) e mais quatro sobre a Torre Eiffel (n. ${ }^{\circ}$, 3 , p. 21,4, p. 29, 7, p. 53, e 11, p. 85).

Pode adiantar-se que alguns jornais "anunciaram» revistas ou outras publicações com gravuras da Exposição: A Illustração (O Tribuno Popular e Correspondencia de Coimbra, por exemplo); Exposição Universal de 1889 - "Vista geral da exposição, com a torre Eiffel, campanario e pharol da mesma torre e os retratos dos cinco engenheiros que dirigiram os trabalhos da exposição, e uma descripção rapida 


\section{Centenário na Imprensa Regional de Coimbra}

O destaque coube, especialmente, à Exposição Universal de Paris (e às suas curiosidades ou maravilhas, como a torre Eiffel, triunfo da técnica e do "génio humano», a nova arte do ferro na contemplação deslumbrante da cidade). Não admira que assim fosse, porque ela constituiu uma grande atracção nacional e internacional (consagrando o desenvolvimento francês nas ciências e na tecnologia). Tanto mais que as exposições, que o século praticamente inventou, (em torno do progresso material, técnico, científico, urbano, etc.), ilustravam as realidades e cs valores de um «novo poder» e de uma «nova civilização» nos caminhos da humanidade.

Foi ela ocasião ou manifestação especial de utilidades e avanços materiais mas também intercâmbio de pensamentos e ideias (realizando-se, por exemplo, dezenas de congressos). Oportunidade e expoente de novos interesses ou mitos, arrastou uma grande "peregrinação de povos».

Não se justifica aqui, de modo algum, qualquer apreciação, por resumida que fosse, das informações disponíveis.

Salientarei apenas que, naturalmente, muitas delas aludem à participação portuguesa na Exposição, a nível de visitantes (entre os quais indivíduos e famílias desta cidade) e de expositores - com referências, por exemplo, a êxitos e prémios obtidos (designadamente por elementos da cidade e da região, entre outros).

Segundo determinadas estatísticas relativas à Exposição (inaugurada, festivamente, em 6 de Maio e encerrada a 6 de Nōembro), terão ido a Paris (além de alguns milhões de franceses da província) um milhão e meio de estrangeiros, dos quais

da mesma; numa folha de $1,12 \times 0,38$ - e Livre d'or de l'Exposition Journal hebdomadaire illustré (Correspondencia de Coimbra).

Refira-se ainda que na Correspondencia de Coimbra se publicou um artigo (tirado do El Liberal) sobre «Uma ascenção à Torre Eiffel impressões de um viajante» (n.o 62, de 9/8/1889. pp. 1-2).

0 mesmo jornal, sob o título de "A revolução franceza" (n. 2 , de $5 / 1 / 1889$, p. 2, col. 3) - informa sobre a iniciativa do Museu Grevin de Paris em "reunir uma colecção de escriptos curiosos sobre a Revolução, documentos historicos, autographos, emblemas, etc., destinados a completar d'uma maneira instructiva, a galeria recentemente inaugurada", indicando-se alguns dos "documentos» que já ali figuram - e, sob o título de «Um panorama monstruoso para a Exposição Universal de Paris» (n. ${ }^{\circ} 10$, de 1/2/1889. p. 3, col. 1), noticia que «Stevens e Gervex exporão no grande certamen d'este anno, em Paris, um enorme panorama, representando todos os personagens illustres que têm vivido em França desde 1789 a 1889, dispostos ou passeando em grupo nos jardins das Tulherias....». 
3500 portugueses $\left({ }^{26}\right)$. Naturalmente de várias condições e com diferentes objectivos.

Adiante-se que ali se deslocou em Setembro, por conta da Câmara Municipal de Lisboa, uma missão oficial de algumas dezenas de operários, integrando representantes das seguintes «classes»: operários de máquinas; alfaiates; caldeireiros; carpinteiros; correeiros; cuteleiros; encadernadores; funileiros; litógrafos; artes cerâmicas; marceneiros; ourives; sapateiros; segeiros; tanoeiros; tipógrafos.

No regresso, incumbia a cada "grupo» apresentar um relatório à câmara (àcerca da visita, observações e estudos feitos no âmbito da especialidade) e proferir conferências especiais nas respectivas associações $\left({ }^{27}\right)$.

Atraindo a atenção de sectores diversos, a própria Coimbra Medica (revista quinzenal de medicina e cirurgia) publicou dois artigos sobre a Exposição, da autoria do seu director, Prof. Dr. Augusto Rocha, exaltando o seu significado e grande interesse, pelos seus ensinamentos, para os próprios médicos e higienistas $\left({ }^{28}\right)$.

Bastante mais se poderia apontar, mas é tempo de concluir, adiantando algumas breves notas finais sobre o tema que abordei.

\section{Conclusão}

Com maior ou menor relevo, o primeiro centenário da revolução ecoou, pois, nas colunas da imprensa de Coimbra e, através delas, no espírito dos seus leitores.

(26) Cf. Correspondencia de Coimbra (n. 96 , de 6/12/1889, p. 1, cols. 1-2) e $O$ Imparcial de Coimbra (n..$^{\circ} 86$, de 26/11/1889, p. 3, cols. 3-4).

(27) Cf. Correspondencia de Coimbra (n. 24 , de 26/3/1889, p. 2 , col. 1), A Voz do Artista (n.o 165, de 8/4/1889, p. 3, cols. 2-3) e O Tribuno Popular (n. 3499 , de 11/9/1889, p. 2, col. 1).

As referidas conferências principiaram em 10 de Novembro, abrindo-as Azedo Gneco, «da classe de ourivesaria» (cf. A Voz do Artista, r.. 187 , de $23 / 11 / 1889$, p. 4 , col. 1 ).

$\left.{ }^{28}\right)$ Artigos intitulados: «Um marco millenario!» (Coimbra Medica, 9. anno, n..$^{\circ} 17$, Coimbra, Imprensa da Universidade, 1889 , pp. 257 -259) e "Exemplos», datado de Paris, 19 de Outubro (ibidem, n..$^{\circ}$. pp. 321-324).

No primeiro, começa, aliás, por realçar o alcance da revolução, afirmando que "Um seculo volvido sobre o poderoso e profundo movimento social, politico, economico e scientifico, que serviu de epilogo na lucta travada para a emancipação do espírito humano, e rasgou no horizonte a alvorada do mundo moderno; - um seculo volvido, a generosa nação da critica e do protesto, de Montaigne a Voltaire, da sciencia e da industria, de Lavoisier a Eiffel e Pasteur. está dando aos povos o exemplo mais sympathico, mais grandioso e commovedor, que desde 


\section{Centenário na Imprensa Regional de Coimbra}

Não apenas a efeméride e as celebrações a que deu azo, mas também alguns juízos de valor sobre 1789, variando entre a exaltação e a condenação.

Atitudes que derivariam de desiguais «leituras» da sua história mas, provavelmente, mais ainda de distintas preocupações quanto ao presente e ao futuro. Afinal, a revolução francesa, mesmo à distância de um século, constituiria um ponto de referência fundamental onde se cristalizavam opiniões, ideias, aspirações e sentimentos contraditórios e actuais.

Tudo isto num século que, na alternância de reacções e de revoluções, consolidou princípios e vias que ela abriu, mas não menos gerou novos problemas e expectativas (sob o influxo da industrialização moderna e da urbanização, de novas ideologias, por exemplo), ampliando ou alterando, assim, as divisões herdadas. No interior (ou na adjacência) de questões fundamentais como estas: na área política - liberalismo e/ou democracia; monarquia ou república?; na área económica - a indústria expoente de desenvolvimento?; na área social - dominação burguesa ou emancipação operária?; na área ideológica - poder temporal e poder espiritual, clericalismo ou laicização?; etc.

Por esses e outros motivos, a rememoração do acontecimento não foi (nem podia ter sido) descomprometida, servindo, em parte, para sugerir temas ou perspectivas globais e como oportunidade de confronto ideológico, de contestação ou crítica de políticas internas ou externas, de instituições, etc.. Ou seja, na história «contada» - a história vivida.

Por outras palavras, sem deixar de interessar por ela própria, a revolução importaria mais pelas «lições» e exemplos que proporcionava.

Reconhecimento, afinal, do seu impacto e das suas projecções, mesmo nesta cidade (relativamente pequena, embora de significativa dimensão cultural) de Coimbra.

A França surgiu, frequentemente, enaltecida. Os defensores da revolução erigiram-na quase em modelo no mundo con-

os seus inicios obscuros até este momento de maravilhosas affirmativas ha presenceado a Historia» (p. 257).

Visitou ele a Exposição - "obra gigantesca, que honra a França, e honra tambem a humanidade» - e numa "Carta de Paris», datada de 6 de Novembro (dia em que findou "essa maravilhosa festa do trabalho», "com os applausos de mais de 300000 espectadores»), dirigida a Joaquim Martins de Carvalho, tocou num assunto de grande importância e actualidade, nessa altura, para a cidade de Coimbra - o sistema de esgotos (sobre os quais Paris fez "uma exposição completissima»). Interesse relacionado com o facto de recentemente se haver aprovado a lei que mandava proceder à construção dos esgotos em Coimbra. E daí que o director de $O$ Conimbricense a haja publicado (n.o 4403, de $12 / 11 / 1889$, p. 2, cols. 2-3). 
temporâneo (criticando, embora, alguns factos graves). Não assim, naturalmente, os adversários daquela, sem, contudo, deixarem de manifestar-lhe apreço por outras páginas da sua história e por determinadas realizações ou contributos da época.

Comportamento ilustrativo da grande importância da França (em termos políticos - inclusive como «capital da revolução» -, culturais, técnicos, etc.) no contexto europeu mas também, provavelmente, de arreigadas inclinações ou tendências em grande parte da mentalidade nacional.

Volvido um século sobre 1789 , a revolução conservava alguma actualidade na imprensa de Coimbra, veiculada em desmedida fraseologia de cariz retórico e romântico. Ao cuidado, nomeadamente, de advogados do liberalismo que havia (e que ela parcialmente inspirara), de paladinos da "classe operária» que confiavam nos seus princípios e avanços, de defensores da «tradição» ou da Igreja que denunciavam as suas ruínas e influências.

Para uns, o «horror» e a «desordem». Para outros, a «luz» que progredia, em «círculos» de mais esperança. Unilateralidade, $\in \mathrm{m}$ qualquer dos casos.

Para todos, certamente, o entusiasmo pelo progresso. Na fama de Paris em 1889, no Campo de Marte, a Exposição Universal e a torre Eiffel (então, o mais alto monumento do globo).

Embora limitados e de discutível interesse, os «ecos» coligidos constituem, ainda assim, determinadas «imagens» e «interpretações» da revolução e, com ela, da própria história do século XIX (sob o signo de irreversíveis mudanças e da crescente hegemonia de distintas ideologias).

A história acontece. $\mathrm{Na}$ diversidade de ideias e de sentimentos. Difícil se torna explicá-la ou compreendê-la. Ainda quando perdura. Ainda quando se esquece. 